\title{
Analysis of Thin Bifacial Silicon Solar Cells with Locally Diffused and Selective Back Surface Field
}

\author{
Adriano Moehlecke*, Vanessa da Conceição Osório, Izete Zanesco \\ Solar Energy Technology Nucleus, Faculty of Physics, Pontifical Catholic University of Rio Grande do \\ Sul-PUCRS, Av. Ipiranga, 6681, P. 96A, TECNOPUC, CEP 90619-900, Porto Alegre, RS, Brazil
}

Received: May 6, 2014; Accepted: August 2, 2014

\begin{abstract}
The aim of this work is to present the development and comparison of thin $\mathrm{n}^{+} \mathrm{pp}^{+}$industrial bifacial silicon solar cells produced with the local screen-printed Al back surface field (BSF) to those with the selective BSF doped with aluminum-boron. To produce solar cells with selective BSF, the boron diffusion based on spin-on dopant was introduced in the process sequence. The thin $\mathrm{SiO}_{2}$ layer $(10 \mathrm{~nm})$ thermally grown did not produce good passivation on the rear face and wafers were contaminated during aluminum diffusion in the belt furnace. The implementation of selectively doped BSF improved the efficiency by reflecting minority charge carriers and the wafer contamination by belt furnace was compensated by boron diffusion. The bifacial solar cells with B-Al selective BSF achieved an efficiency of $13.7 \%$ / 8.9\% (front / rear illumination) and presented lower sensitivity to the belt furnace processing and to the quality of the rear surface passivation.
\end{abstract}

Keywords: thin solar cells, bifacial solar cells, locally diffused Al-BSF, selective BSF

\section{Introduction}

In the last decade, significant cost reductions in the $\mathrm{kWh}$ obtained from photovoltaic modules were related to the "economy-of-scale" benefits, the solar cell efficiency increase and the lower consumption of high purity silicon per Wp. For instance, wafer thickness was reduced from $350 \mu \mathrm{m}$ to $180 \mu \mathrm{m}$. However, the silicon wafer still represents $58 \%$ of the cell cost and $42 \%$ of the PV module production costs ${ }^{1}$. The use of thinner wafers can lead to cost reduction, but high quality surface passivation is needed to achieve high efficiency devices ${ }^{2}$. Under the point of view of industrial processing, equipments need to be adapted for handling thin wafers ${ }^{3}$ and the standard $\mathrm{n}^{+} \mathrm{pp}^{+}$silicon solar cells, with the rear surface fully covered by the Al thick layer, have to be modified in order to avoid the wafer bowing ${ }^{4,5}$. The Al layer forms a back surface field that reflects the minority charge carriers away from the rear contact, reducing the recombination. The bow is produced during the thermal step performed to diffuse $\mathrm{Al}$ into a silicon wafer and it is a result of the different thermal coefficients of expansion of aluminum layer and silicon. The wafer bowing can lead to cracking during soldering and lamination processes used to assemble the PV modules.

In order to avoid the wafer bowing, solar cells with a rear metal grid and surface passivation based on dielectric films have been studied. For instance, Lee et al. ${ }^{6}$ produced large area PERC (passivated emitter rear cell) solar cells and achieved the efficiency of $17.7 \%$ by using $148.6 \mathrm{~cm}^{2}$ FZ (float-zone) Si wafers and the efficiency of $17.2 \%$ in $156.8 \mathrm{~cm}^{2}$ multicrystalline Si wafers. The wafers used had a thickness of $130 \mu \mathrm{m}$ and the rear side was passivated with the $\mathrm{SiO}_{\mathrm{x}} / \mathrm{SiN}_{\mathrm{x}} / \mathrm{SiO}_{\mathrm{x}} \mathrm{N}_{\mathrm{y}}$ stack deposited by PECVD

*e-mail: moehleck@pucrs.br (plasma-enhanced chemical vapor deposition) and also by implementing the local back contacts using a laser. Front emitter was doped with phosphorus diffused in a quartz tube furnace by using $\mathrm{POCl}_{3}$ as source. With the same goal of reducing bowing, $\mathrm{Gu}$ et al. ${ }^{5}$ implemented a BSF (back surface field) region by using a thin layer composed by boron and aluminum pastes deposited by screen-printing. The authors reported that the metallization paste thickness was reduced while the efficiency was not diminished. Therefore, thinner layer of doping paste fired at temperatures up to $800{ }^{\circ} \mathrm{C}$ can help the development of low bowing silicon solar cells.

Bifacial cells have been studied since the 1960 s years $^{7}$. This kind of cell is active in both faces and can convert the radiation reflected by the surrounding areas ${ }^{8}$. The bifacial cells also can be applied in static concentrators with different designs ${ }^{9,10,11}$. Several bifacial structures were developed by using silicon as starting material ${ }^{7,12}$. Simplified bifacial cells are based on the standard monofacial structure with one pn junction, one BSF region and the metal grid on both faces. This way, the use of a metal grid on the rear face avoids the bow and thinner wafers can be used. To obtain high electric current when the solar cell is illuminated by BSF region, the minority charge carrier diffusion length needs to be larger than the wafer thickness. Thus, the carriers photogenerated far from pn junction could be collected. Taking into account similar front and rear passivation, minority carrier diffusion length has to be over twice the wafer thickness to allow the production of symmetric bifacial cells, that is, cells with similar short-circuit electric current for front and rear side illumination $^{13,14}$.

High efficiency bifacial cells based on $\mathrm{n}^{+} \mathrm{pp}^{+}$structure and using standard $200 \mu \mathrm{m}$ thick Cz-grown (Czochralski) 
silicon wafers were reported by Yang et al. ${ }^{15}$. Homogeneous $\mathrm{n}^{+}$and $\mathrm{p}^{+}$regions were obtained by $\mathrm{P}$ and $\mathrm{B}$ diffusion performed at $870{ }^{\circ} \mathrm{C}$ and $1020^{\circ} \mathrm{C}$, respectively. $\mathrm{POCl}_{3}$ and $\mathrm{BBr}_{3}$ liquid sources were used in the diffusion processes. $\mathrm{SiN}_{\mathrm{x}}$ antireflection/passivation coating was deposited on both faces as well as the screen printed metal grid. The large area devices $\left(149 \mathrm{~cm}^{2}\right)$ achieved the front and rear efficiencies of $16.6 \%$ and $12.8 \%$, respectively. Janben et al. ${ }^{16}$ also used p-type $\mathrm{Cz}-\mathrm{Si}$ and screen-printed contacts, but instead to implement a uniform $\mathrm{p}^{+}$region on the rear face, an Al metal grid was deposited to produce a local BSF. Front and rear surfaces were covered with an $\mathrm{a}-\mathrm{SiN}_{\mathrm{x}}: \mathrm{H}$ layer deposited by PECVD. The front and rear efficiency of $17 \%$ and $10.3 \%$, respectively, were reported ${ }^{15}$.

Standard $\mathrm{p}^{+} \mathrm{nn}^{+}$structure with homogenous doped regions was applied to produce small $\left(4 \mathrm{~cm}^{2}\right) \mathrm{FZ}$ and $\mathrm{Cz}-$ silicon solar cells, achieving efficiencies of $19.1 \% / 18.1 \%$ (front / rear illumination) and $17.7 \% / 15.2 \%$, respectively. The wafers employed were $250 \mu \mathrm{m}$ thick and the metal grid was defined by photolithography and deposited by e-beam evaporation at high vacuum ${ }^{17,18}$. Buck et al. ${ }^{19}$ obtained efficiencies of $15.9 \% / 13.4 \%$ (front/rear illumination) in large area $\left(144 \mathrm{~cm}^{2}\right) \mathrm{p}^{+} \mathrm{nn}^{+}$devices fabricated by using $\mathrm{FZ}$ silicon wafer (200 mm thick) and with metal grid deposited by screen-printing. They also used $\mathrm{BBr}_{3}$ and $\mathrm{POCl}_{3}$ as diffusion sources to form $\mathrm{p}^{+}$and $\mathrm{n}^{+}$homogeneously doped regions.

The thin silicon bifacial cells have been developed by implementing $\mathrm{n}^{+} \mathrm{pp}^{+}, \mathrm{p}^{+} \mathrm{nn}^{+}$or $\mathrm{n}^{+} \mathrm{p}$ structures. In small area devices $\left(4 \mathrm{~cm}^{2}\right)$ with evaporated contacts, front and rear efficiencies of $17 \% / 14.9 \%$ and $16 \% / 13 \%$ were reported for $\mathrm{p}^{+} \mathrm{nn}^{+}$and $\mathrm{n}^{+} \mathrm{pp}^{+}$cells, respectively ${ }^{20}$. Homogenous $\mathrm{n}^{+}$and $\mathrm{p}^{+}$regions were obtained by $\mathrm{P}$ and $\mathrm{B}$ diffusion in $140 \mu \mathrm{m}$ thick $\mathrm{Cz}$ wafers. Using screen printed emitter and BSF as well as evaporated contacts, Pérez et al. ${ }^{21}$ reported small area bifacial devices that achieved the efficiencies of $14.2 \% / 13.6 \%$. When screen-printed metal grids were implemented, efficiencies were lower: $11.6 \% / 10.8 \%$ for $\mathrm{n}^{+} \mathrm{pp}^{+}$cells and $8.3 \% / 8.0 \%$ for $\mathrm{p}^{+} \mathrm{nn}^{+}$ones. Bifacial $\mathrm{n}^{+} \mathrm{np} \mathrm{p}^{+}$ cells with a thickness of $130 \mu \mathrm{m}$ were developed by using a fully industrial in-line process ${ }^{22}$. The $\mathrm{n}^{+}$and $\mathrm{p}^{+}$regions were implemented by screen-printing deposition of phosphorus and boron pastes and the dopants were co-diffused into silicon wafers in the belt furnace. Metal grids were also deposited by screen-printing. Small area $\left(4 \mathrm{~cm}^{2}\right)$ devices achieved the front/rear efficiency of $13.6 \% / 10.4 \%{ }^{22}$. Recart ${ }^{23}$ developed larger bifacial devices $\left(24.7 \mathrm{~cm}^{2}\right)$ in $120 \mu \mathrm{m}$ thick $\mathrm{Cz}$ wafers by using screen-printed boron pastes to obtain $\mathrm{p}^{+} \mathrm{BSF}$, but $\mathrm{n}^{+}$emitter was formed by phosphorus diffusion utilizing $\mathrm{POCl}_{3}$ as source. The $\mathrm{n}^{+} \mathrm{pp}^{+}$solar cells reached the efficiencies of $14.3 \%$ and $10.8 \%$ for front and rear side illumination, respectively. Thin bifacial cells with $\mathrm{n}^{+}$front emitter and the rear surface passivated with a $\operatorname{SiN}_{\mathrm{x}}$ layer was presented by Steckemetz et al. ${ }^{24}$. The $\mathrm{SiN}_{\mathrm{x}}$ layer produced an effective passivation on the rear face and $14.6 \%$ / 13.6\% (front/rear illumination) efficient devices were reported. Wafer thickness was $140 \mu \mathrm{m}$ and devices had the area of $4 \mathrm{~cm}^{2}$.

The aim of this paper is to present the development and comparison of thin $\mathrm{n}^{+} \mathrm{pp}^{+}$bifacial cells produced by using the locally aluminum doped back surface field and by using the selective region doped with aluminum and boron. The process to obtain the selective $\mathrm{p}^{+}$region was based on boron deposition by spin-on and diffusion in the standard quartz tube followed by Al grid screen-printing and diffusion in a belt furnace. As far as we know, the combination of both processes to accomplish the selective BSF was used for the first time to produce thin bifacial solar cells. The devices were fabricated on solar grade $\mathrm{Cz}$ silicon wafers with the thickness of around $150 \mu \mathrm{m}$ by using industrial techniques. Surface passivation of a $\mathrm{SiO}_{2}$ thin layer was also analyzed.

\section{Material and Methods}

The starting material was $\mathrm{Cz}$-silicon, p-type, boron doped, 1-20 $\Omega . c m,<100>$ orientation. The thickness of the wafers was of around $150 \mu \mathrm{m}$. The saw damage of the wafers was removed by immersing them in a $\mathrm{KOH}$ solution and the etching time defined the thickness of the wafers. Texture etch was carried out in an alkaline solution also based on $\mathrm{KOH}$, but with lower concentration.

To develop the $\mathrm{n}^{+} \mathrm{pp}^{+}$solar cells with locally diffused Al BSF, the process sequence shown in Figure 1a was used. Wafers were cleaned in RCA standard solutions and a $100 \mathrm{~nm}$ thick $\mathrm{SiO}_{2}$ layer was grown at $1000^{\circ} \mathrm{C}$ in a quartz tube furnace. Photoresist was spin coated on one face and the oxide layer was etched away in a buffered HF solution. After cleaning the wafers, the phosphorus diffusion was accomplished in a quartz tube furnace at $875{ }^{\circ} \mathrm{C}$ with $\mathrm{POCl}_{3}$ as source. Phosphorus profile was measured by ECV (electrochemical capacitance-voltage) technique. The diffusion processes formed the $\mathrm{n}^{+}$emitter with a sheet resistance of $32 \Omega / \square$, with a junction depth of around $0.6 \mathrm{~mm}$ and surface concentration $\left(\mathrm{C}_{\mathrm{S}}\right)$ of approximately $3.3 \times 10^{19}$ $\mathrm{cm}^{-3}$. Phosphorus silicate glass (PSG) and $\mathrm{SiO}_{2}$ layer were removed in an HF bath and wafers were cleaned in RCA solutions. A $10 \mathrm{~nm}$ thick $\mathrm{SiO}_{2}$ layer was grown at $800{ }^{\circ} \mathrm{C}$ in order to passivate the surfaces. Cells without oxide were also processed to evaluate the passivation effectiveness of the $\mathrm{SiO}_{2}$ layer. The titanium dioxide antireflection coating (ARC) was deposited by e-beam evaporation at high vacuum on the front face and the metal grid was deposited by screenprinting on both faces. In the first batches, ARC was not deposited on the rear face in order to avoid the misleading effects related to the $\mathrm{TiO}_{2}$ etching process performed during the firing of Al paste. The silver paste was deposited on the front face and the $\mathrm{Al}$ paste was screen-printed on the rear face. The metal pastes were dry and co-fired in a belt furnace. The diffusion/firing temperature $\left(\mathrm{T}_{\text {Firing }}\right)$ used for cells without oxide layer was $840{ }^{\circ} \mathrm{C}$ and for those with a $10 \mathrm{~nm}$ thick $\mathrm{SiO}_{2}$ layer was $850{ }^{\circ} \mathrm{C}^{25}$. The metal grid was a standard H-pattern with two busbars, covering $9.5 \%$ of the surfaces (front and rear). Pseudo-square cells $(80 \mathrm{~mm} \times 80 \mathrm{~mm}$ ) were obtained after performing the edge isolation step.

The $\mathrm{n}^{+} \mathrm{pp}^{+}$cells with selective BSF region doped with boron and Al were processed as summarized in Figure $1 \mathrm{~b}$. After the texture etch and the RCA cleaning, $\mathrm{p}^{+}$region was obtained by boron spin-on deposition and diffusion in a quartz tube furnace at $1000{ }^{\circ} \mathrm{C}$. Boron diffusion was performed before phosphorus in order to avoid the production of a very deep pn junction and thicker dead layer, 
which occurs when phosphorus is diffused in supersaturation conditions. The oxide layer needed to mask the $\mathrm{p}^{+}$region from the phosphorus diffusion was grown in the same thermal step of the boron diffusion. Photoresist was spin coated on the boron-doped face and the oxide layer was etched away in a buffered HF solution. Phosphorus was diffused at $875^{\circ} \mathrm{C}\left(\mathrm{POCl}_{3}\right.$ as source). Phosphorus and boron silicate glasses (PSG and BSG) were etched away by means of HF solution and RCA cleaning was performed. Silicon dioxide layer was grown and $\mathrm{TiO}_{2}$ ARC was deposited. $\mathrm{Ag}$ and $\mathrm{Al}$ metal grids were screen-printed on the front and rear face, respectively, and were co-fired in the belt furnace. The diffusion/firing temperatures were the same used for cells with local Al-BSF. Boron diffusion resulted in the doped region with a thickness of around $1 \mu \mathrm{m}$, surface concentration of $3.6 \times 10^{19} \mathrm{~cm}^{-3}$ and sheet resistance of $30 \Omega / \square$. The $\mathrm{n}^{+}$emitter presented the sheet resistance of approximately $32 \Omega / \square$.

All the devices were characterized under standard conditions $\left(100 \mathrm{~mW} / \mathrm{cm}^{2}, \mathrm{AM} 1.5 \mathrm{G}\right.$ and $\left.25^{\circ} \mathrm{C}\right)$ in a solar simulator calibrated with silicon solar cells previously measured at CalLab - FhG-ISE (Fraunhofer-Institut für Solare Energiesysteme), Germany. Two-dimensional distribution of minority charge carrier lifetime $(\tau)$ was obtained by $\mu$-PCD (microwave photoconductivity decay) with the WT1000-PV device of Semilab. Minority charge carrier diffusion length $\left(\mathrm{L}_{\mathrm{D}}\right)$ was calculated from LBIC (light beam induced current) measurements performed with the WT1000-PV equipment.

\section{Results and Discussion}

Table 1 presents the open circuit voltage $\left(\mathrm{V}_{\mathrm{OC}}\right)$, the shortcircuit current density $\left(\mathrm{J}_{\mathrm{SC}}\right)$, the fill factor $(\mathrm{FF})$, the efficiency $(\eta)$ and the current symmetry factor (CSF) of the bifacial solar cells with local Al-BSF. The average values were calculated from the results of at least three cells. Quality of bifacial cells can be evaluated by the current symmetry factor CSF (also called "bifaciality") defined as the ratio of the short-circuit current when the cell is illuminated on the rear face to the one when the cell is illuminated on the front face.

The solar cells with $\mathrm{SiO}_{2}$ passivated surfaces presented an average $\mathrm{V}_{\mathrm{OC}}$ of $9-10 \mathrm{mV}$ higher than that from unpassivated ones. The short-circuit current was increased by implementing $\mathrm{SiO}_{2}$ film when the cell was illuminated

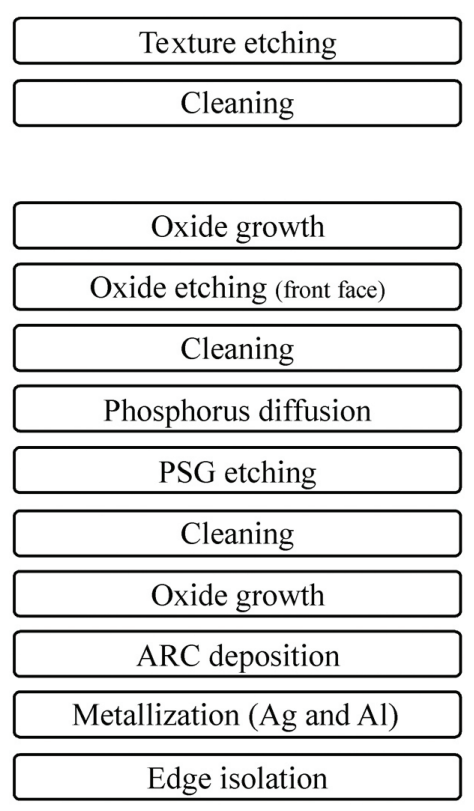

(a)

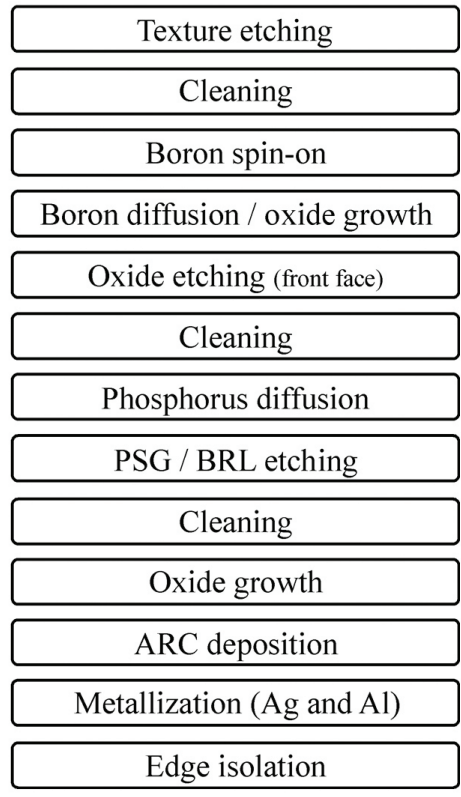

(b)

Figure 1. Bifacial solar cell process sequences: (a) devices with local Al-BSF and (b) with selective BSF (Al and B).

Table 1. Average electrical characteristics of bifacial solar cells with Al locally diffused BSF.

\begin{tabular}{lccccc}
\hline \multicolumn{5}{c}{ Front illumination (on n p junction) } \\
\hline & $\mathbf{T}_{\text {Firing }}\left({ }^{\circ} \mathbf{C}\right)$ & Voc $(\mathbf{m V})$ & Jsc (mA/cm $)$ & FF & $\boldsymbol{\eta}(\mathbf{\%})$ \\
\hline Without $\mathrm{SiO}_{2}$ & 840 & $572 \pm 3$ & $29.7 \pm 0.6$ & $0.69 \pm 0.02$ & $11.7 \pm 0.2$ \\
$\mathrm{SiO}_{2}(10 \mathrm{~nm})$ & 850 & $583 \pm 3$ & $30.1 \pm 0.4$ & $0.69 \pm 0.01$ & $12.1 \pm 0.2$ \\
\hline \multicolumn{7}{c}{ Current symmetry factor - CSF } \\
\hline $\mathrm{Without} \mathrm{SiO}_{2}$ & 840 & $0.16 \pm 0.01$ & \\
$\mathrm{SiO}_{2}(10 \mathrm{~nm})$ & 850 & $0.14 \pm 0.05$ & \\
\hline
\end{tabular}


on the front face. The CSF was very low for uncovered and $\mathrm{SiO}_{2}$ covered solar cells. Thus, the rear passivation was not effective and/or the minority carrier lifetime was very low, resulting in the minority carrier diffusion length smaller than the wafer thickness. The Figure 2 shows the two-dimensional distribution of the minority charge carrier diffusion length in passivated and unpassivated devices. The bifacial solar cells without $\mathrm{SiO}_{2}$ layer presented an average diffusion length of $70 \mu \mathrm{m}$. In oxide-passivated devices, the average $\mathrm{L}_{\mathrm{D}}$ was of around $90 \mu \mathrm{m}$, also lower than the wafer thickness.

Table 2 summarizes the electrical characteristics of the best solar cells produced with local BSF. In order to assess the values of minority carrier lifetimes, front surface recombination velocity $\left(\mathrm{S}_{\mathrm{f}}\right)$, rear surface recombination velocity $\left(\mathrm{S}_{\mathrm{r}}\right)$ and specific series resistance $\left(\mathrm{r}_{\mathrm{s}}\right)$, the bifacial cells were simulated by using the PC1D computer program $^{26}$ and these parameters were adjusted to fit in well the simulated $\mathrm{V}_{\mathrm{OC}}, \mathrm{J}_{\mathrm{SC}}, \mathrm{FF}$ and $\eta$ to the experimental ones. Bearing in mind that Al-BSF covers $9.5 \%$ of the rear surface, an effective surface recombination velocity $\left(\mathrm{S}_{\mathrm{r}-\mathrm{ef}}\right)$ was considered by using the method presented by LagoAurrekoetxea ${ }^{27}$. The surface recombination velocity was set in $1 \times 10^{7} \mathrm{~cm} / \mathrm{s}$ for the surfaces not covered by $\mathrm{Al}$ or $\mathrm{SiO}_{2}$. The following parameters were set to obtain the results presented in Table 2 for the cells without oxide: $S_{f}=1 \times 10^{7} \mathrm{~cm} / \mathrm{s}$, $\mathrm{S}_{\mathrm{r}-\mathrm{ef}}=9.05 \times 10^{6} \mathrm{~cm} / \mathrm{s}, \tau=10 \mu \mathrm{s}$ and $\mathrm{r}_{\mathrm{s}}=2.8 \Omega \mathrm{cm}^{2}$. When the cells were passivated with the thermally-grown $\mathrm{SiO}_{2}$ layer, the parameters used in the simulations that led to the best I-V (electric current-voltage) curve fitting were: $\mathrm{S}_{\mathrm{f}}=$ $1 \times 10^{5} \mathrm{~cm} / \mathrm{s}, \mathrm{S}_{\mathrm{r}-\mathrm{ef}}=2.5 \times 10^{4} \mathrm{~cm} / \mathrm{s}, \tau=10 \mu \mathrm{s}$ and $\mathrm{r}_{\mathrm{s}}=2.8 \Omega . \mathrm{cm}^{2}$. Minority carrier lifetime was very low and high phosphorus doped emitter normally presents a high recombination velocity of around $10^{5} \mathrm{~cm} / \mathrm{s}$, even if surfaces are $\mathrm{SiO}_{2}$ coated. The combination of low minority carrier lifetime and high surface recombination led to the low current symmetry factor of these bifacial cells.

In order to evaluate the contamination and gettering mechanisms during the process, minority carrier lifetime (or bulk lifetime) was measured after each processing step and the results are shown in the Figure 3 and Figure 4. Oxides and emitter were etched away with an HF solution and the

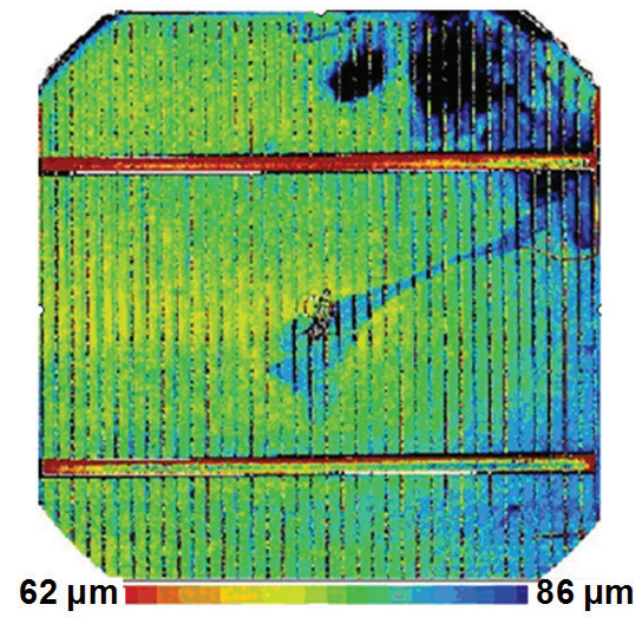

(a)

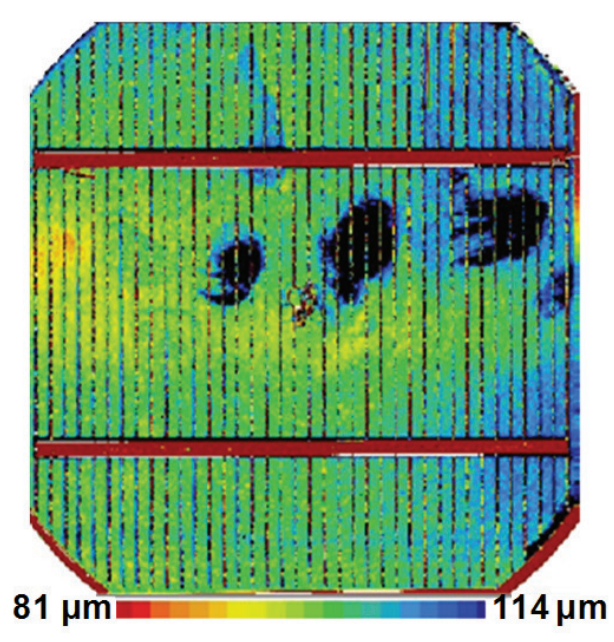

(b)

Figure 2. Two-dimensional distribution of the minority carrier diffusion length of the solar cells with local Al-doped BSF: (a) without $\mathrm{SiO}_{2}$ layer (scale from $62 \mu \mathrm{m}$ to $\left.86 \mu \mathrm{m}\right)$ and (b) with $\mathrm{SiO}_{2}(81 \mu \mathrm{m}$ to $114 \mu \mathrm{m})$.

Table 2. Electrical characteristics of the best bifacial solar cells with Al locally diffused BSF and results from simulation by means of the PC1D device-modeling program.

\begin{tabular}{|c|c|c|c|c|c|c|}
\hline \multicolumn{7}{|c|}{ Front illumination (on $\mathbf{n}^{+} \mathbf{p}$ junction) } \\
\hline & $\mathbf{T}_{\text {Firing }}\left({ }^{\circ} \mathrm{C}\right)$ & Results & Voc $(\mathrm{mV})$ & $\mathrm{Jsc}\left(\mathrm{mA} / \mathrm{cm}^{2}\right)$ & FF & $\eta(\%)$ \\
\hline \multirow[t]{2}{*}{ Without $\mathrm{SiO}_{2}$} & 840 & $\operatorname{Exp}^{*}$ & 573 & 29.3 & 0.709 & 11.9 \\
\hline & & $\operatorname{Sim} \bullet$ & 579 & 29.2 & 0.698 & 11.8 \\
\hline \multirow[t]{2}{*}{$\mathrm{SiO}_{2}(10 \mathrm{~nm})$} & 850 & Exp & 585 & 30.5 & 0.688 & 12.3 \\
\hline & & Sim & 584 & 31.0 & 0.694 & 12.5 \\
\hline \multicolumn{7}{|c|}{ Current symmetry factor - CSF } \\
\hline \multirow{2}{*}{ Without $\mathrm{SiO}_{2}$} & 840 & Exp & & 0.16 & & \\
\hline & & Sim & & 0.10 & & \\
\hline \multirow[t]{2}{*}{$\mathrm{SiO}_{2}(10 \mathrm{~nm})$} & 850 & Exp & & 0.14 & & \\
\hline & & Sim & & 0.13 & & \\
\hline
\end{tabular}

*Experimental results; $\bullet$ Simulated results. 


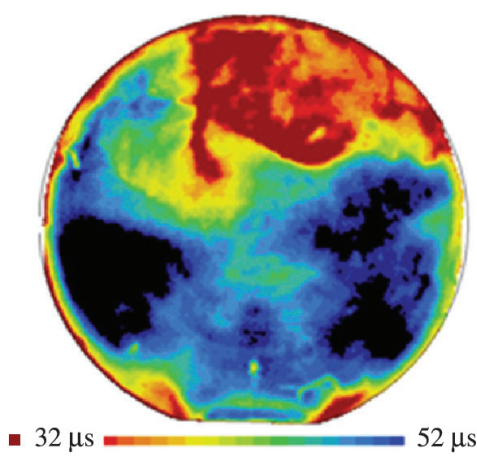

(a)

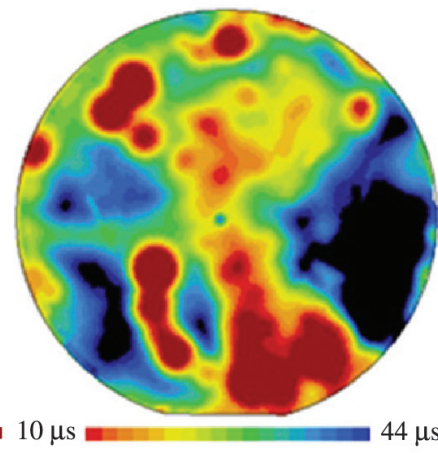

(b)

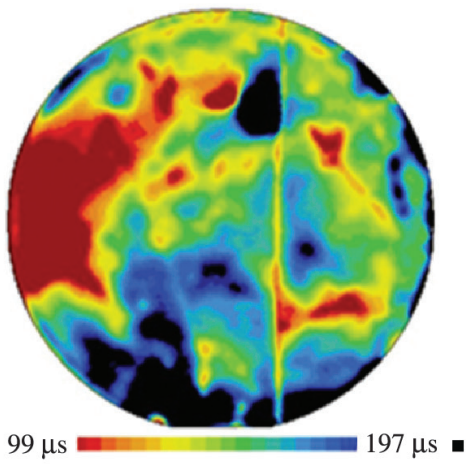

(c)

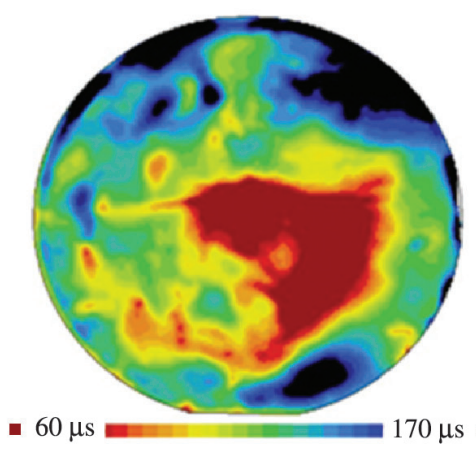

(d)

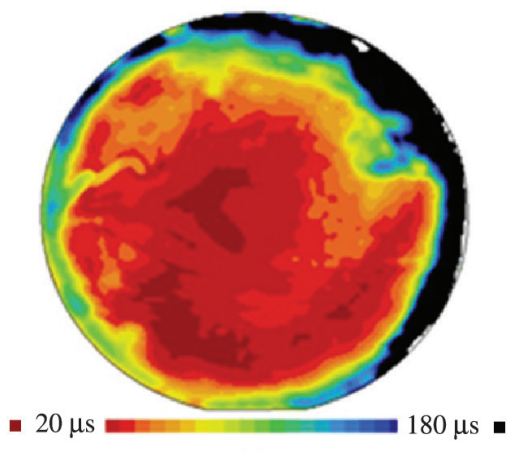

(e)

Figure 3. Minority charge carrier lifetime distribution after: (a) texture etching (32 $\mu$ s to $52 \mu \mathrm{s})$, (b) oxide growth (10 $\mu \mathrm{s}$ to $44 \mu \mathrm{s})$, (c) P diffusion $(99 \mu \mathrm{s}$ to $197 \mu \mathrm{s})$, (d) passivation oxide growth $(60 \mu \mathrm{s}$ to $170 \mu \mathrm{s})$ and (e) metallization (20 $\mu$ s to $180 \mu \mathrm{s})$.

$\mathrm{CP} 4$ one $\left(\mathrm{HNO}_{3}: \mathrm{HF}: \mathrm{CH}_{3} \mathrm{COOH}\right)$. During the measurements, samples were immersed in an iodine+ethanol solution to passivate the surfaces. The metallization comprises three thermal steps in belt furnace, two of them for drying of the metal pastes (from $150{ }^{\circ} \mathrm{C}$ to $300{ }^{\circ} \mathrm{C}$ ) and one step for firing these pastes $\left(840-850^{\circ} \mathrm{C}\right)$. To analyze the effect of this fabrication step on bulk lifetime, wafers were thermally processed without the metal grid. The results showed that bulk lifetime was enhanced by $\mathrm{P}$ gettering and the metallization step degraded the minority carrier lifetime.

In the Table 3 are summarized the results obtained from $\mathrm{n}^{+} \mathrm{pp}^{+}$cells with selective BSF formed by boron diffusion over the whole rear surface and by Al locally diffused. Comparing the cells with local Al-BSF (Table 1) to those with $\mathrm{Al} / \mathrm{B}-\mathrm{BSF}$, we can observe that the current symmetry factor was increased from 0.14 to 0.73 for passivated devices and from 0.16 to 0.64 in unpassivated cells. Oxide layer did not improve the cell output parameters.

The electrical parameters of the best solar cells with selective Al/B-BSF are presented in Table 4. The most efficient device presented the efficiency of $13.7 \%$ under front illumination (pn junction) and $8.9 \%$ under rear illumination (BSF region). Results from similar devices with smaller area $\left(24.7 \mathrm{~cm}^{2}\right)$ were reported by Recart ${ }^{23}$, achieving front efficiency slightly higher, but with the busbars outside the active area. The rear efficiency was $1.9 \%$ (absolute) higher than the obtained in this work because ARC was used.

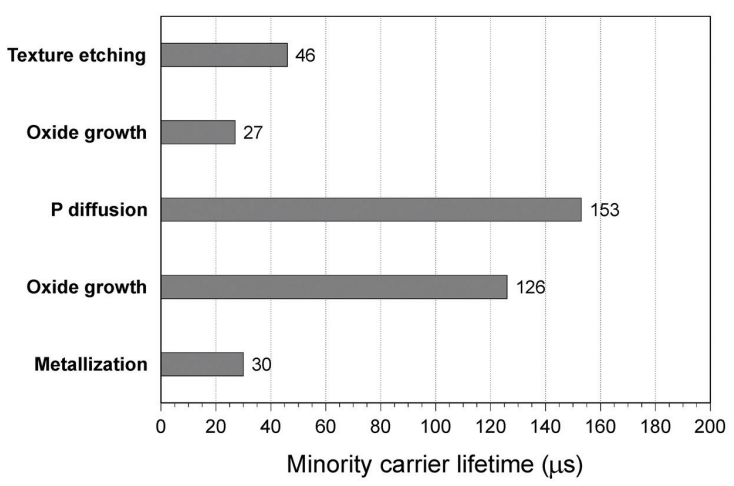

Figure 4. Average minority charge carrier lifetime after each processing step used to produce local-Al doped BSF.

Deposition of the ARC on the rear face can enhance the $\mathrm{J}_{\mathrm{s}}$ of around $2 \mathrm{~mA} / \mathrm{cm}^{2}$ and the efficiency can be improved to $10 \%$.

The PC1D computer program was used for modeling these cells and the internal parameters such as $\tau, \mathrm{S}_{\mathrm{f}}, \mathrm{S}_{\mathrm{r}}$ and $r_{s}$ were adjusted to fit simulation results to the experimental ones. For passivated cells, input parameters set to simulate the cell performance were: $\mathrm{S}_{\mathrm{f}}=7 \times 10^{5} \mathrm{~cm} / \mathrm{s}, \mathrm{S}_{\mathrm{r}}=7 \times 10^{5} \mathrm{~cm} / \mathrm{s}$, $\tau=10 \mu$ s and $r_{s}=3.4 \Omega . \mathrm{cm}^{2}$. To model the devices with nonpassivated surfaces, parameters used were: $\mathrm{S}_{\mathrm{f}}=1 \times 10^{7} \mathrm{~cm} / \mathrm{s}$, 
$\mathrm{S}_{\mathrm{r}}=1 \times 10^{7} \mathrm{~cm} / \mathrm{s}, \tau=20 \mu$ s and $\mathrm{r}_{\mathrm{s}}=2 \Omega . \mathrm{cm}^{2}$. The thin $\mathrm{SiO}_{2}$ layer did not produce an effective surface passivation for cells with Al/B-BSF. Likewise the solar cells with local-Al BSF, the bulk lifetime, between $10 \mu$ s to $20 \mu \mathrm{s}$, used to simulate the solar cell with selective BSF, was also very low. The average $\mathrm{L}_{\mathrm{D}}$ obtained from LBIC measurements reached values as high as $460 \mu \mathrm{m}$ (devices without $\mathrm{SiO}_{2}$ ) and $500 \mu \mathrm{m}$ (oxide-passivated cells), as shown in Figure 5. The high $\mathrm{L}_{\mathrm{D}}$ was not due to the high bulk lifetime, but due to the boron BSF that reduced the recombination rate on the rear face and it was considered in the estimation of $\mathrm{L}_{\mathrm{D}}$ from LBIC measurements.

Table 3. Average electrical characteristics of bifacial solar cells with Al/B - BSF.

\begin{tabular}{|c|c|c|c|c|c|}
\hline \multicolumn{6}{|c|}{ Front illumination (on $\mathbf{n}^{+} \mathbf{p}$ junction) } \\
\hline & $\mathbf{T}_{\text {Firing }}\left({ }^{\circ} \mathrm{C}\right)$ & Voc $(\mathrm{mV})$ & $\mathrm{Jsc}\left(\mathrm{mA} / \mathbf{c m}^{2}\right)$ & FF & $\eta(\%)$ \\
\hline Without $\mathrm{SiO}_{2}$ & 840 & $595 \pm 2$ & $31 \pm 1$ & $0.73 \pm 0.01$ & $13 \pm 1$ \\
\hline $\mathrm{SiO}_{2}(10 \mathrm{~nm})$ & 850 & $577 \pm 13$ & $29.4 \pm 0.6$ & $0.70 \pm 0.01$ & $11.9 \pm 0.3$ \\
\hline \multicolumn{6}{|c|}{ Rear illumination (on selective BSF region) } \\
\hline Without $\mathrm{SiO}_{2}$ & 840 & $587 \pm 1$ & $19.7 \pm 0.9$ & $0.74 \pm 0.01$ & $8.6 \pm 0.5$ \\
\hline $\mathrm{CSF}$ & & & $0.64 \pm 0.05$ & & \\
\hline $\mathrm{SiO}_{2}(10 \mathrm{~nm})$ & 850 & $585 \pm 5$ & $21.5 \pm 1.3$ & $0.72 \pm 0.04$ & $9.0 \pm 0.1$ \\
\hline $\mathrm{CSF}$ & & & $0.73 \pm 0.06$ & & \\
\hline
\end{tabular}

Table 4. Experimental and simulated electrical parameters of the best bifacial solar cells with Al/B-doped BSF region. The antireflection coating was not deposited on the rear face.

\begin{tabular}{|c|c|c|c|c|c|c|}
\hline \multicolumn{7}{|c|}{ Front illumination (on $\mathbf{n}^{+} \mathbf{p}$ junction) } \\
\hline & $\mathbf{T}_{\text {Firing }}\left({ }^{\circ} \mathrm{C}\right)$ & Results & Voc $(\mathrm{mV})$ & $\operatorname{Jsc}\left(\mathbf{m A} / \mathbf{c m}^{2}\right)$ & FF & $\eta(\%)$ \\
\hline \multirow[t]{2}{*}{ Without $\mathrm{SiO}_{2}$} & 840 & Exp* & 597 & 31.2 & 0.736 & 13.7 \\
\hline & & Sim• & 597 & 31.5 & 0.733 & 13.8 \\
\hline \multirow{2}{*}{$\mathrm{SiO}_{2}(10 \mathrm{~nm})$} & 850 & Exp & 587 & 29.8 & 0.693 & 12.1 \\
\hline & & Sim & 593 & 31.5 & 0.664 & 12.4 \\
\hline \multicolumn{7}{|c|}{ Rear illumination (on selective BSF region - no ARC) } \\
\hline \multirow[t]{4}{*}{ Without $\mathrm{SiO}_{2}$} & 840 & Exp & 588 & 20.3 & 0.748 & 8.9 \\
\hline & & $\mathrm{CSF}$ & & 0.65 & & \\
\hline & & Sim & 585 & 19.2 & 0.765 & 8.6 \\
\hline & & $\mathrm{CSF}$ & & 0.61 & & \\
\hline \multirow[t]{4}{*}{$\mathrm{SiO}_{2}(10 \mathrm{~nm})$} & 850 & Exp & 582 & 22.4 & 0.687 & 9.0 \\
\hline & & CSF & & 0.75 & & \\
\hline & & Sim & 578 & 17.6 & 0.727 & 7.4 \\
\hline & & CSF & & 0.56 & & \\
\hline
\end{tabular}

*Experimental results; $\bullet$ Simulated results.

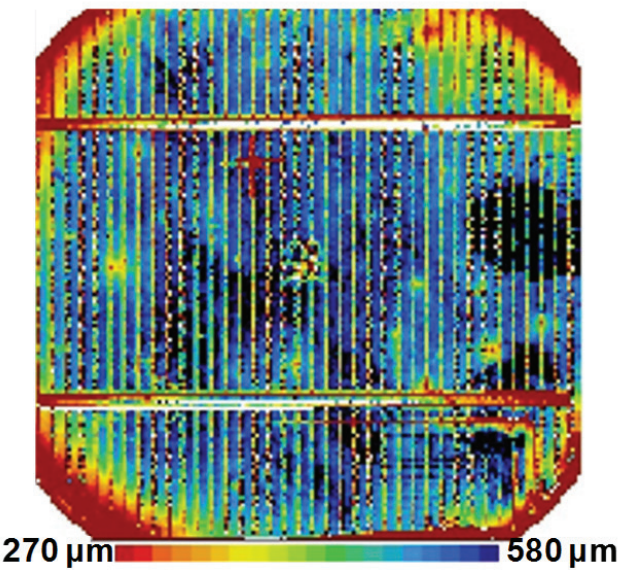

(a)

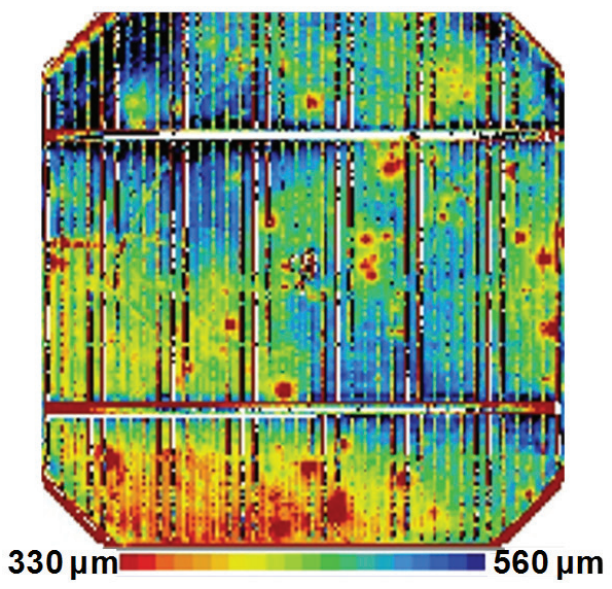

(b)

Figure 5. Two-dimensional distribution of the minority carrier diffusion length of the bifacial cells with boron/aluminum BSF: (a) unpassivated device $(270 \mu \mathrm{m}$ to $580 \mu \mathrm{m})$ and (b) $\mathrm{SiO}_{2}$ - passivated solar cell $(330 \mu \mathrm{m}$ to $560 \mu \mathrm{m})$. 


\section{Conclusions}

Local Al-doped BSF and selectively doped Al/B-BSF were implemented in thin bifacial silicon solar cells.

Concerning the solar cells with locally doped BSF, the analysis of the minority charge carrier lifetime showed that phosphorus diffusion produced gettering, but due to the contamination in belt furnace, bulk lifetime decreased and the final value was similar to the initial. Besides, the minority carrier diffusion length calculated from LBIC measurements was smaller than the wafer thickness. In addition, the silicon dioxide growth at $800^{\circ} \mathrm{C}$ did not result in an effective surface passivation. The combined effect of low bulk lifetime and unpassivated rear surface led to the small CSF, lower than 0.16 . Therefore, the structure was not suitable for bifacial devices.

The solar cells with a selective Al-B BSF presented higher current symmetry factors of around 0.70 . Although the silicon dioxide layer established a poor rear surface passivation, the BSF in whole face allowed the achievement of average minority carrier diffusion lengths three times higher than the wafer thickness. The most efficient bifacial

\section{References}

1. Goodrich A, Hacke P, Wang Q, Sopori B, Margolis R, James TL, et al. A wafer-based monocrystalline silicon photovoltaics road map: utilizing known technology improvement opportunities for further reductions in manufacturing costs. Solar Energy Materials and Solar Cells. 2013; 114:110-135. http://dx.doi.org/10.1016/j.solmat.2013.01.030.

2. Mauck M, Sims P, Rand J and Barnett A. Thin silicon solar cells. In: Markvart T, Castañer L, editors. Solar cells: materials, manufacture and operation. Oxford: Elsevier; 2005. p. 121161.. http://dx.doi.org/10.1016/B978-185617457-2/50007-X.

3. Fischmann C, Giesen T, Böttinger F, Wertz R and Hoffmeister M. Automated handling and transport of crystalline photovoltaic wafers. In: Proceedings of the 25th European Photovoltaic Solar Energy Conference and Exhibition; 2010; Valencia, Spain. Valencia: WIP; 2010. p. 1677-1681.

4. Hilali MM, Gee JM and Hacke P. Bow in screen-printed backcontact industrial silicon solar cells. Solar Energy Materials and Solar Cells. 2007; 91(13):1228-1233. http://dx.doi. org/10.1016/j.solmat.2007.04.010.

5. Gu X, Yu X, Xu J, Fan R and Yang D. Towards thinner and low bowing silicon solar cells: form the boron and aluminum co-doped back surface field with thinner metallization film. Progress in Photovoltaics: Research and Applications. 2013; 21:456-461.

6. Lee D-Y, Lee H-H, Yong Ahn J, Jung Park H, Kim JH, Kwon HJ, et al. A new back surface passivation stack for thin crystalline silicon solar cells with screen-printed back contacts. Solar Energy Materials and Solar Cells. 2011; 95(1):26-29. http://dx.doi.org/10.1016/j.solmat.2010.05.004.

7. Cuevas A. The early history of bifacial solar cells. In: Proceedings of the 20th European Photovoltaic Solar Energy Conference; 2005; Barcelona, Spain. Barcelona: WIP; 2005. p. $801-805$

8. Cuevas A, Luque A, Eguren J and del Alamo J. 50\% more output power from an albedo-collecting flat panel using bifacial solar cells. Solar Energy. 1982; 29(5):419-420. http://dx.doi. org/10.1016/0038-092X(82)90078-0. cell was fabricated without $\mathrm{SiO}_{2}$ layer and achieved an efficiency of $13.7 \%$ and $8.9 \%$ for front $\left(\mathrm{n}^{+}\right.$face) and rear $\left(\mathrm{p}^{+}\right.$face) illumination, respectively, the latter without ARC. The simulation of this cell with ARC on the rear face showed an improvement of around $2 \mathrm{~mA} / \mathrm{cm}^{2}$ in the $\mathrm{J}_{\mathrm{SC}}$ and, consequently, the efficiency could rise to approximately $10 \%$. The results obtained in this work were similar to that reported to bifacial devices with small area, but larger solar cells with spin-on boron deposition were developed and busbars were considered inside active area.

To sum up, thin bifacial solar cells need a selective BSF region when high quality surface passivation cannot be implemented in the industrial process.

\section{Acknowledgements}

The authors acknowledge the financial support provided by state utility CEEE-D (contract number CEEE-D 9942397) and by the Brazilian financing agencies FINEP (contract number 01.10.0020.02, ref. 2109/09) and CNPq (process number 563581/2010-7).

9. Moehlecke A and Krenzinger A. Modules assembled with diffuse reflectors for photovoltaic bifacial cells. In: Proceedings of the 10th European Photovoltaic Solar Energy Conference; 1991; Lisbon, Portugal. Lisbon: WIP; 1991. p. 967-970.. http:// dx.doi.org/10.1007/978-94-011-3622-8_247.

10. Zanesco I and Lorenzo E. Optimisation of an asymmetric static concentrator: the PEC-44D. Progress in Photovoltaics: Research and Applications. 2002; 10(5):361-376. http://dx.doi. org/10.1002/pip.431.

11. Norton B, Eames PC, Mallick TK, Huang MJ, McCormack SJ, Mondol JD, et al. Enhancing the performance of building integrated photovoltaics. Solar Energy. 2011; 85(8):1629-1664. http://dx.doi.org/10.1016/j.solener.2009.10.004.

12. Coello J, Cañizo C and Luque A. Review on bifacial solar cell structures for industrialization. In: Proceedings of the 21st European Photovoltaic Solar Energy Conference; 2006; Dresden, Germany. Dresden: WIP; 2006. p. 1358-1361.

13. Moehlecke A, Zanesco I, Cañizo C and Luque A. Experimental comparison between $\mathrm{p}$ and $\mathrm{n}$ bases for bifacial solar cells. In: Proceedings of the 13th European Photovoltaic Solar Energy Conference; 1995; Nice, France. Nice: WIP; 1995. p. 967-970.

14. Jimeno JC, Bueno G, Lago R, Freire I, Pérez L, Recart F, et al. Low cost using ultra-thin bifacial cells. In: Proceedings of the 22nd European Photovoltaic Solar Energy Conference; 2007; Milan, Italy. Milan: WIP; 2007. p. 875-878.

15. Yang L, Ye QH, Ebong A, Song WT, Zhang GJ, Wang JX, et al. High efficiency screen printed bifacial solar cells on monocrystalline $\mathrm{Cz}$ silicon. Progress in Photovoltaics: Research and Applications. 2011; 19(3):275-279. http://dx.doi. org/10.1002/pip.1018.

16. Janßen L, Windgassen H, Bätzner DL, Bitnar B and Neuhaus H. Silicon nitride passivated bifacial Cz-silicon solar cells. Solar Energy Materials and Solar Cells. 2009; 93(8):1435-1439. http://dx.doi.org/10.1016/j.solmat.2009.03.015.

17. Moehlecke A, Zanesco I and Luque A. Practical high efficiency bifacial solar cells. In: Conference Record of the IEEE First World Conference on Photovoltaic Energy Conversion; 1994; Hawaii, USA. Hawaii: IEEE; 1995. p. 1663-1666. 
18. del Canizo C, Moehlecke A, Zanesco I, Tobias I and Luque A. Analysis of a technology for CZ bifacial solar cells. IEEE Transactions on Electron Devices. 2001; 48(10):2337-2341. http://dx.doi.org/10.1109/16.954474.

19. Buck I, Kopecek R, Libal J, Herguth A, Peter K, Rover I, et al. Industrial screen printed n-type silicon solar cells with front boron emitter and efficiencies exceeding 17\%. In: Proceedings of the 21st European Photovoltaic Solar Energy Conference; 2006; Dresden, Germany. Dresden: WIP; 2006. p. 1264-1267.

20. Pan AC, Cañizo C and Luque A. Thin bifacial silicon solar cells. In: Proceedings of the 22th European Photovoltaic Solar Energy Conference; 2007; Milan, Italy. Milan: WIP; 2007. p. 1438-1441.

21. Pérez L, Coello J, Freire I, Varner K, Lago R, Bueno G, et al. Global processes for the fabrication of low cost bifacial solar cells. In: Proceedings of the 20th European Photovoltaic Solar Energy Conference; 2005; Barcelona, Spain. Barcelona: WIP; 2005. p. 891-894.

22. Recart F, Hoces I, Azkona N, Freire I, Pérez Manzano L, Fano $\mathrm{V}$, et al. Bifacial thin solar cells with screen printed emitters and metallizations. In: Proceedings of the 23rd European Photovoltaic Solar Energy Conference; 2008; Valencia, Spain. Valencia: WIP; 2008. p. 1893-1896.
23. Recart F. Evaluation of screen-printing as metallization technology for efficient solar cells. [Doctor dissertation]. Spain: University of the Basque Country; 2001.

24. Steckemetz S, Metz A and Hezel R. Thin Cz-silicon solar cells with rear silicon nitride passivation and screen printed contacts. In: Proceedings of the 17th European Photovoltaic Solar Energy Conference; 2001; Munich, Germany. Munich: WIP; 2001. p. 1902-1906.

25. Conceição VC, Moehlecke A and Zanesco I. Analysis of the metal paste diffusion/firing process and the $\mathrm{SiO}_{2}$ passivation in thin bifacial solar cells with $\mathrm{p}^{+}$local region. In: Proceedings of the IV Brazilian Solar Energy Congress and V ISES Latin American Conference; 2012; São Paulo, Brazil. São Paulo: ABENS; 2012. p. 1-8. In Portuguese.

26. Basore PA and Clugston DA. PC1D version 5: 32-bit solar cell modeling on personal computers. In: Proceedings of the 26th IEEE Photovoltaic Specialists Conference; 1997; Anaheim, USA. Anaheim: IEEE; 1997. p. 207-210.

27. Lago-Aurrekoetxea R. Surface and bulk recombination in silicon solar cells based on phosphorus-aluminum technology. [Doctor dissertation]. Spain: Technical University of Madrid; 2002. 